\title{
HUBUNGAN AKUMULASI TIMBAL PADA RAMBUT MASYARAKAT PENGUMPUL LIMBAH BATUBARA DENGAN PENYAKIT HIPERTENSI
}

\author{
Dini Arista Putri, Adi Heru Sutomo, Widharto Prawirohardjono \\ Program Studi Keselamatan dan kesehatan kerja, Fakultas Kedokteran, \\ Universitas Gadjah Mada \\ jmkbengkulu@gmail.com
}

\begin{abstract}
The water contamination in one place can affect the other places located far from the source of pollution. One of the rivers that are polluted is Bengkulu river. One of the causes of pollution in Bengkulu river that is coal waste originating from coal mine company in the upstream of the river, which is still in service until now. The coal handling treatment as crushing, grinding, washing, drying and low temperature combustion can cause any harmful chemical substances like lead. Lead can get into the human body through the digestive tract absorption or through the respiratory tract (inhalation) and skin absorption. One way of disposal of heavy metal elements from the body is to accumulate in the hair, so the hair analysis is a good way to estimate the content of heavy metal elements in the body and determine its connection with hypertension. The purpose of this study is to determine the content of lead in a coal waste accumulates in hair of coal waste collectors society in Bengkulu river associated with hypertension. This study is an analytic observational study with cross sectional study design. The case that will be studied is about the accumulation of hair lead of coal waste collectors society in Bengkulu river against hypertension. The study location is in Bengkulu river. Sample examination was conducted by Atomic Absorption Spectrophotometry (AAS) analytical methods, and then performed statistical tests to determine its connection with hypertension. The result of this study showed, from 40 respondents there were 14 respondents $(35 \%)$ who had hair lead levels $>12 \mu \mathrm{g} / \mathrm{g}$ suffered from hypertension and 13 respondents $(32.5 \%)$ who had hair lead levels $>12 \mu \mathrm{g} / \mathrm{g}$ but did not suffered from hypertension, and $\mathrm{p}(0.03)<0.05$ value which indicates a significant association. Significant association between the levels of lead in the hair of coal waste collectors society in Bengkulu river with hypertension
\end{abstract}

Keywords: Waste Coal, Lead, Hypertension

\begin{abstract}
Abstrak : Pencemaran air di suatu tempat dapat berpengaruh terhadap tempat lain yang lokasinya jauh dari sumber pencemaran. Salah satu sungai yang mengalami pencemaran yaitu Sungai Bengkulu. Salah satu penyebabsungai Bengkulu tercemar yaitu limbah batubara yang berasal dari perusahaan penambangan batubara di hulu sungai yang masih beroperasi hingga kini. Perlakuan penanganan batubara seperti peremukan, penggerusan, pencucian, pengeringan dan pembakaran dengan suhu rendah dapat menimbulkan adanya zat-zat kimia berbahaya seperti timbal. Timbal dapat masuk ke dalam tubuh manusia melalui serapan saluran pencernaan (digesti) atau melalui saluran pernafasan (inhalasi) dan absorbsi kulit. Pembuangan unsur-unsur logam berat dari tubuh adalah salah satunya dengan jalan mengakumulasikannya di dalam rambut, maka analisis rambut adalah cara yang baik untuk memperkirakan kandungan unsur-unsur logam berat dalam tubuh dan mengetahui hubungannya dengan penyakit hipertensi. Tujuan dari penelitian adalah untuk mengetahui adanya kandungan Timbal dari limbah batubara yang terakumulasi pada rambut masyarakat pengumpul limbah batubara di sungai Bengkulu yang dihubungkan dengan Penyakit hipertensi. Penelitian ini merupakan penelitian observasional analitik dengan desain penelitian bersifat cross sectional. kasus yang akan diteliti yaitu tentang akumulasi timbal pada rambut masyarakat pengumpul limbah batubara di air sungai Bengkulu terhadap penyakit hipertensi. Lokasi penelitian dilakukan di Sungai Bengkulu, Pemeriksaan sampel dengan metode analisis Atomic Absorbtion Spectrofotometri (AAS), kemudian dilakukan uji statistik untuk mengetahui hubungannya dengan penyakit hipertensi. Hasil penetian
\end{abstract}


inimenunjukkan dari 40 responden, ada 14 responden (35\%) yang memiliki kadar timbal dirambut $>12 \mu \mathrm{g} / \mathrm{g}$ yang menderita hipertensi dan 13 responden $(32,5 \%)$ yang memiliki kadar timbal dirambut $>12 \mu \mathrm{g} / \mathrm{g}$ tetapi tidak menderita hipertensi dan dilihat dari nilai $\mathrm{p}(0,03)<0,05$ yang menunjukkan adanya hubungan yang signifikan. Adanya hubungan yang bermakna antara kadar timbal dalam rambut pengumpul limbah batubara di air sungai bengkulu dengan penyakit hipertensi

Kata Kunci: Limbah Batubara, Timbal, Hipertensi

Pencemaran air di suatu tempat dapat berpengaruh terhadap tempat lain yang lokasinya jauh dari sumber pencemaran. Hal ini karena gaya grafitasi, air yang dapat mengalir dari tempat yang tinggi ke tempat yang lebih rendah sehingga air yang berada di gunung akan mengalir ke sungai, pantai dan berakhir di laut (Wiryono, 2013).

Hampir 57 sungai lintas propinsi, negara dan sungai strategis nasional dari 33 provinsi dinyatakan $70-75 \%$ sungai yang dipantau telah tercemar baik tercemar ringan,sedang maupun berat (Kementerian Lingkungan Hidup, 2014).

Sungai Bengkulu merupakan salah satu sungai yang mengalami pencemaran yang disebabkan perusahaan penambangan batubara di hulu sungai yang masih beroperasi hingga kini. Batubara setelah selesai ditambang, pada umumnya diolah terlebih dahulu. Hal ini disebabkan karena masih tercampurnya pengotor bersama batubara, dan perlunya spesifikasi tertentu saat pemasaran sehingga dilakukan pengurangan dan mereduksi senyawa-senyawa kimia yang tidak dikehendaki pabrik peleburan. Perlakuan secara fisik yang dilakukan antara lain peremukan, penggerusan, pencucian, pengeringan dan pembakaran dengan suhu rendah memungkinkan zat-zat kimia berbahaya ikut terbuang termasuk logam berat seperti timbal. Berdasarkan uji pendahuluan dengan mengambil limbah batubara di 3 titik yaitu sungai serut, sungai bengkulu dan muara pantai panjang Bengkulu, batubara yang diuji mengandung timbal sebesar 2,96 ppm, 5,03 ppm dan 8, 13 ppm.

Proses masuknya timbal ke dalam tubuh dapat melalui makanan dan minuman, udara dan perembesan atau penetrasi pada selaput atau lapisan kulit.Timbal yang masuk ke dalam tubuh manusia, tidak semua diserap oleh tubuh. Hanya sekitar 5-10\% dari jumlah timbal yang masuk melalui makanan dan sebesar 30\% dari jumlah yang terhirup yang akan diserap oleh tubuh dan hanya $15 \%$ yang mengendap pada jaringan tubuh seperti rambut dan lebih dari $90 \%$ logam timbal yang terserap oleh darah berikatan dengan sel-sel darah merah (eritrosit), serta sisanya akan turut terbuang bersama sisa metabolisme seperti urin dan feces (Palar, 2012).

Timbal $(\mathrm{Pb})$ bersifat toksik, karsinogenik, bioakumulator dan biomagnifikasi. Bioakumulasi timbal dapat terjadi pada kuku, hati dan rambut (Marianti, 2013). Berdasarkan KEPMEN RI No.1406 tahun 2002, pemeriksaan kadar timbal dengan biomarker manusia dapat menggunakan spesimen darah, urin dan rambut. Rambut merupakan bahan biologis yang menarik karena kemudahan pengumpulan sampel dan pengawetan. Konsentrasi logam dalam rambut telah digunakan untuk tujuan medis sebagai tanda diagnostik penyakit atau sebagai indikator paparan polutan (Kubova, 1994). Rambut merupakan bahan yang dapat digunakan untuk penentuan bahan anorganik dan organik terutama ketika cairan tubuh (darah, urin dan lain-lain) tidak tersedia untuk menyelidiki peristiwa keracunan atau efek dari sumber lingkungan, gizi atau pekerjaan pada tubuh. Rambut digunakan sebagai salah satu jaringan pilihan oleh Badan Perlindungan Lingkungan Amerika (EPA) dalam menentukan paparan logam beracun.

Berdasarkan penelitian Saptutyningsih (2009) di Kabupaten Bantul, timbal mengakibatkan timbulnya 97.628 kasus penurunan IQ pada anak, 14 kasus jantung koroner, 107 kasus kematian dan 12.462 kasus hipertensi. penyakit hipertensi dapat terjadi akibat adanya peningkatan tekanan darah. Berdasarkan penelitian Beeverset al., (1976) di daerah skotlandia barat bahwa tekanan darah tinggi berhubungan dengan kadar timbal yang tinggi pada darah dimana berprevalensi tinggi penya- 
kit kardiovaskuler di daerah tersebut Besarnya risiko menderita penyakit hipertensi pada pekerja STIMBALU yang memiliki Timbal darah kadar tinggi $(>5 \mu \mathrm{g} / \mathrm{dl})$ untuk menderita hipertensi dibandingkan dengan Timbal kadar rendah $(<5 \mu \mathrm{g} / \mathrm{dl})$ dan penelitian Deyot et al, (2013) menyatakan bahwa ada hubungan antara kadar Timbal dalam darah dengan kejadian hipertensi. Berdasarkan penelitian Sanna (2007) menunjukkan adanya hubungan yang significant antara kadar timbal di dalam darah dan kadar timbal di dalam rambut sehingga rambut juga dapat digunakan sebagai biomarker paparan timbal selain darah.

Penelitian ini dilakukan untuk mengetahui seberapa besar kadar timbal yang terakumulasi di dalam air sungai Bengkulu dan rambut masyarakat pengumpul limbah batubara serta mengetahui hubungannya dengan penyakit hipertensi akibat paparan timbal sehingga dapat memberikan informasikan kepada pemerintah dan masyarakat pengumpul batubara.

\section{BAHAN DAN CARA KERJA}

Penelitian yang dilakukan merupakan penelitian observasional analitik yang menjelaskan adanya hubungan antara variabel melalui pengujian hipotesa. Sedangkan pelaksanaan penelitian dengan metoda survei dan pemeriksaan laboratorium dengan desain penelitian bersifat cross sectional. Subjek dalam penelitian ini adalah masyarakat pengumpul limbah batubara di sungai bengkulu Teknik pengambilan sampel dengan pendekatan purposive dengan jumlah sampel sebanyak 40 responden. Dengan kriteria pemilihan yaitu kriteria inklusi: ma-syarakat pengumpul limbah batubara di sungai bengkulu, bersedia menjadi responden, berje-nis kelamin laki-laki, masa kerja $\geq 3$ tahun, lama kerja $\geq 5$ jam/hari, usia 20-50 tahun dan kriteria eksklusi: mengonsumsi obat antihipertensi, tidak bekerja sebagai pengumpul limbah batubara, memiliki pekerjaan ganda.

Data primer diperoleh dari observasi, kuisioner dan pengukuran timbal dirambut dan air sungai menggunakann alat Atomic Absorbtion Spectrofotometri (AAS) di labora- torium kimia Universitas Sriwijaya dan tensimeter. Data kuantitatif dari kuisioner dan pengukuran diolah dengan menggunakan program stata.

\section{HASIL}

Pengukuran Kadar timbal diair sungai Bengkulu yang merupakan lokasi penelitian menunjukkan adanya kadar timbal terlarut maupun timbal total. Timbal total dari ke tiga titik didapatkan sebesar $0,0766 \mu \mathrm{g} / \mathrm{mL} ; 0,0825$ $\mu \mathrm{g} / \mathrm{mL} ; 0,0471 \mu \mathrm{g} / \mathrm{mL}$ sedangkan timbal terlarut didapatkan sebesar $0,0471 \mu \mathrm{g} / \mathrm{mL}$; $0,0412 \mu \mathrm{g} / \mathrm{mL} ; 0,0295 \mu \mathrm{g} / \mathrm{mL}$.

Tabel 1 Range reponden penelitian

\begin{tabular}{cc}
\hline Timbal di rambut & $0-206,3 \mu \mathrm{g} / \mathrm{g}$ \\
Usia & $23-49$ tahun \\
Masa kerja & $3-8$ tahun \\
Lama kerja & $5-12 \mathrm{jam} / \mathrm{hari}$ \\
Tekanan darah sistolik & $100-194 \mathrm{mmHg}$ \\
Tekanan darah diastolik & $59-107 \mathrm{mmHg}$ \\
\hline
\end{tabular}

Analisis awal Responden yang memiliki kadar timbal di rambut yang melebihi ambang batas beresiko 7,52 kali untuk menderita hipertensi dengan nilai $\mathrm{p}(0,02)<0,05$ yang menunjukkan bahwa memiliki hubungan yang signifikan antara timbal dirambut dengan hipertensi, dan Secara statistik konsumsi makanan asin dengan $\mathrm{p}(0,331)$ dan kebiasaan minum kopi dengan $\mathrm{p}(0,167)$ menunjukkan hubungan yang tidak signifikan karena bernilai $>0,05$. Tetapi secara klinis responden yang mengkonsumsi makanan asin dengan OR sebesar 2,4 memiliki risiko2,4 kali untuk menderita hipertensi dan responden yang memiliki kebiasaan minum kopi dengan nilai OR sebesar 5,5 memiliki resiko 5,5 kali untuk mengalami hipertensi.

Tabel 2 Final model: Hubungan dan besar resiko antara hipertensi dengan timbal di rambut, konsumsi makanan asin dan kebiasaan minum kopi

\begin{tabular}{cccccc}
\hline Hipertensi Odd ratio & Std. Err & $\mathbf{Z}$ & $\mathbf{P}>|\mathbf{z}|$ & $\mathbf{( 9 5 \%}$ CI) \\
\hline $\begin{array}{c}\text { Timbal di } \\
\text { rambut }\end{array}$ & 7,17 & 6,507 & 2,17 & 0,030 & $1,209-452,481$ \\
$\begin{array}{c}\text { Konsumsi } \\
\text { makanan } \\
\quad \text { asin }\end{array}$ & 2,41 & 1,803 & 0,82 & 0,412 & $0,368-11,470$ \\
$\begin{array}{c}\text { Kebiasaan } \\
\text { minum } \\
\quad \text { kopi } \\
\text { cons }\end{array}$ & 3,27 & 3,104 & 1,24 & 0,213 & $0,507-21,043$ \\
\hline
\end{tabular}


Berdasarkan Final model, Variabel yang memiliki nilai $\mathrm{p}$-value lebih dari 0,05 dikeluarkan secara bertahap dengan mempertimbangkan perubahan nilai OR, perubahan nilai OR yang lebih dari $10 \%$ tetap diikutsertakan karena merupakan variabel pengganggu, Pada tabel 1, variabel merokok tidak diikutsertakan. Hal ini dikarenakan perubahan OR yang didapatkan dibawah dari $10 \%$ dan variabel yang dapat dinyatakan sebagai variabel pengganggu yaitu variabel konsumsi makanan asin dan variabel kebiasaan minum kopi. Dapat disimpulkan bahwa responden yang memiliki kadar timbal didalam rambut $>\mathrm{NAB}$ beresiko 7,16 kali untuk menderita hipertensi dibandingkan responden yang memiliki kadar timbal dirambut $\angle \mathrm{NAB}$. Nilai risiko yang didapatkan dari final model yaitu 7,16 merupakan nilai murni pengaruh timbal rambut terhadap terjadinya hipertensi karena variabel-variabel pengganggu sudah dikontrol secara statistik.

Berdasarkan nilai P-value $>0,05$ konsumsi makanan asis dan kebiasaan minum kopi memiliki hubungan yang tidak bermakna tetapi secra klinis dilihat dari nilai OR responden konsumsi makanan asin beresiko 2,4 kali untuk menderita hipertensi dan responden yang memiliki kebiasaan minum kopi berresiko 3,27 kali untuk menderita hipertensi.

\section{PEMBAHASAN}

Pada penelitian pendahuluan telah didapatkan bahwa batubara yang menjadi sumber pekerjaan masyarakat disekitar sungai Bengkulu mengandung timbal sebesar 2,96 ppm, 5,03 ppm dan 8,13 ppm. Penelitian Daniel et al.,(2006) juga telah membuktikan adanya timbal didalam batubara sebesar $0,008 \mu \mathrm{g} / \mathrm{g}$. Limbah batubara dari perusahaan tambang batubara yang berada dihulu sungai, banyak yang masuk ke badan air sehingga terbawa arus sampai ke hilir sungai. Pada awal penelitian telah dilakukan pengukuran kadar timbal dengan sampel air sungai yang diambil dari 3 titik aliran sungai dikota Bengkulu. Titik pertama yang letaknya dekat dengan perusahaan tambang batubara, yang juga merupakan titik intake air PDAM, titik ke dua diambil dengan memperkirakan titik tengah dari titik pertama dan titik ke tiga,yaitu berada di daerah Tanjung Agung, untuk titik yang ke tiga berlokasi di hilir sungai atau tepatnya di muara pantai.

Timbal dapat berada dalam badan perairan secara alamiah dan sebagai dampak dari aktivitas manusia. Secara alamiah, timbal yang masuk ke badan perairan melalui pengkristalan timbal di udara dengan bantuan air hujan, disamping itu proses korosifikasi dari batuan mineral akibat hempasan gelombang dan angin juga menjadi jalur sumber masuknya timbal ke badan perairan, dan dari akibat-akibat aktivitas manusia seperti pertambangan.

Hasil analisis kadar timbal di air sungai dengan menggunakan alat Atomic Absorbtion Spectrophotometer diketahui bahwa terdapat kandungan timbal di dalam air baik timbal total maupun timbal terlarut, dengan hasil yang didapat kadar timbal di titik awal lebih besar dibandingkan titik akhir yang semakin ke hilir sehingga memungkinkan adaya pengaruh dari batubara yang menyebabkan sungai menjadi mengandung timbal yaitu timbal total sebesar $0,0766 \mu \mathrm{g} / \mathrm{ml} ; 0,0825 \mu \mathrm{g} / \mathrm{mL} ; 0,0471$ $\mu \mathrm{g} / \mathrm{mL}$ dan timbal terlarut sebesar 0,0471 $\mu \mathrm{g} / \mathrm{mL} ; 0,0412 \mu \mathrm{g} / \mathrm{mL} ; 0,0295 \mu \mathrm{g} / \mathrm{mL}$. Berdasarkan peraturan daerah propinsi Bengkulu No. 6 Tahun 2005, batasan timbal yang terkandung di dalam air sungai berdasarkan kelas I,II dan III yaitu $0,03 \mathrm{mg} / \mathrm{L}$ maka dapat dikatakan beberapa titik dari sungai yang diteliti telah tercemar logam berat timbal.

Paparan air berisiko akan bervariasi tergantung pada individu, keadaan, dan jumlah air yang dikonsumsi. Timbal dapat dinyatakan sebagai polutan yang sangat toksik dan berbahaya karena sifatnya yang sukar terurai. Sifat inilah yang dapat menyebabkan timbal dapat terakumulasi dalam jaringan tubuh makhluk hidup sehingga dapat menyebabkan keracunan secara akut dan kronis bahkan dapat menyebabkan kematian.

Bentuk-bentuk kimia dari senyawa $\mathrm{Pb}$, merupakan faktor penting yang mempengaruhi tingkah laku $\mathrm{Pb}$ dalam tubuh manusia. Senyawa $\mathrm{Pb}$ organik relatif lebih mudah untuk 
diserap tubuh melalui selaput lendir atau lapisan kulit, bila dibandingkan dengan senyawa $\mathrm{Pb}$ anorganik. Sebagian besar $\mathrm{Pb}$ yang terhirup pada saat bernafas akan masuk ke dalam pembuluh darah paru-paru. Tingkat penyerapan itu sangat dipengaruhi oleh ukuran partikel dari senyawa $\mathrm{Pb}$ yang ada dan volume udara yang mampu dihirup pada saat bernafas. Makin kecil ukuran partikel debu serta makin besarnya konsentrasi $\mathrm{Pb}$ yang diserap oleh tubuh. Logam $\mathrm{Pb}$ yang masuk ke paru-paru melalui peristiwa pernafasan akan terserap dan berikatan dengan darah paru-paru untuk kemudian diedarkan ke seluruh jaringan dan organ tubuh lebih dari $90 \%$ logam $\mathrm{Pb}$ yang terserap oleh darah berikatan sel-sel darah merah.

Ekskresi timbal berjalan sangat lambat dalam darah kurang lebih 25 hari, pada jaringan lunak 40 hari sedangkan pada tulang 25 tahun. Ekskresi yang lambat ini menyebabkan timbal mudah terakumulasi dalam tubuh baik dalam pajanan okupasional maupun non okupasional (Nordberg, 1998). Timbal di dalam tubuh terutama terikat pada gugus - $\mathrm{SH}$ dalam molekul protein dan menyebabkan terjadinya hambatan pada aktivitas kerja sistem enzim. Timbal bersirkulasi dalam darah setelah diabsorpsi dari usus, terutama hubungannya dengan sel darah merah (eritrosit). Selanjutnya didistribusikan ke dalam jaringan lunak seperti tubulus ginjal dan sel hati, lalu disimpan dalam tulang, rambut dan gigi (Darmono, 2001).

Masyarakat pengumpul batubara yang berada disungai Bengkulu dikumpulkan di bawah tenda dan dibiarkan untuk istirahat sekitar 10 menit lalu responden dipanggil satu per satu untuk dilakukan wawancara dan pengukuran tekanan darah. Pengukuran tekanan darah dilakukan dalam posisi duduk dan santai menggunakan alat tensimeter manual dan digital. Setelah itu dilakukan pengambilan rambut.

Kadar timbal dikategorikan normal berkisar $40-80 \mu \mathrm{g} / \mathrm{dL}$ dan dalam kadar 80$120 \mu \mathrm{g} / \mathrm{dL}$ termasuk dalam kategori toleransi, proses ekskresi yang lama dalam darah selama 25 hari memungkinkan timbal terakumulasi didalam rambut, setelah didalam rambut akumulasi akan terjadi bertahun-tahun dan tidak tdapat terdeposisi karena rambut banyak mengandung protein struktural yang tersusun oleh asam-asam amino sistein yang mengandung gugus ikatan disulfida (-s-s-) dan sistein yang mengandung gugus sulfhidril (-SH) yang berkemampuan mengikat logam berat timbal dengan sangat kuat (Palar, 2012).

Akumulasi timbal didalam rambut dapat menyebabkan besarnya kadar timbal di dalam rambut walaupun batasan normal timbal didalam rambut yaitu $\measuredangle 2 \mu \mathrm{g} / \mathrm{g}$ (Autopsi administration hospital) (Santoso, 2012). Hasil pengukuran kadar timbal di dalam rambut, didapatkan jumlah kadar timbal terbesar di dalam rambut sebesar $206,3 \mu \mathrm{g} / \mathrm{g}$ dan yang terkecil $0 \mu \mathrm{g} / \mathrm{g}$ dengan rerata $37.34975 \mu \mathrm{g} / \mathrm{g}$.

Dari 40 responden, responden yang memiliki kadar timbal di rambut melebihi ambang batas $12 \mu \mathrm{g} / \mathrm{g}$ ada 14 responden (35\%) yang menderita hipertensi dan 13 responden $(32,5 \%)$ yang memiliki kadar timbal dirambut $>12 \mu \mathrm{g} / \mathrm{g}$ tetapi tidak menderita hipertensi. Berdasarkan hasil uji statistik, kadar timbal di dalam rambut dengan hipertensi memiliki hubungan yang signifikan karenanilai $p$-value yang dihasilkan $\mathrm{p} 0,03<0,05$ dan dari nilai $\mathrm{OR}$ yang didapatkan sebesar 7,52 menyatakan bahwa kadar timbal di rambut merupakan faktor resiko 7,52 kali untuk terjadinya hipertensi.

Hasil penelitian ini sejalan dengan penelitian Pasorong et al.,(2007) yang menyatakan bahwa kadar timbal didalam tubuh memiliki resiko 7,42 kali untuk menderita hipertensi, sedangkan responden dengan kadar timbal yang besar tetapi tidak menderita hipertensi mungkin dapat terjadi karena daya tahan tubuh yang berbeda-beda pada setiap orang. Dari beberapa responden banyak mengeluh untuk sulit mengingat-ingat sesuatu dan dilihat dari fisik responden yang diteliti banyak dalam keadaan kurus.

Berdasarkan penelitian hipertensi merupakan keadaan tekanan darah sistolik lebih dari $140 \mathrm{mmHg}$ dan tekanan diastolik lebih dari $90 \mathrm{mmHg}$. Semakin tinggi tekanan darah, semakin tinggi risiko kerusakan pada jantung dan pembuluh darah diorgan utama seperti otak dan ginjal. Sehingga jika tidak dikontrol 
hipertensi dapat menyebabkan serangan jantung, pembesaran jantung, gagal jantung, gagal ginjal, kebutaan dan gangguan kognitif (WHO, 2013).

Hipertensi dapat disebabkan oleh timbal karena didalam darah, timbal secara langsung mempengaruhi sistem peredaran darah sehingga dapat meningkatkan produksi Reactive Oxygen Species (ROS). ROS dapat meningkatkan tekanan darah secara langsung dan mempengaruhi perubahan atherosclerosis dalam darah arteri dan gangguan jantung (Farmand et al., 2005). Pada paparan timbal kronis juga menyebabkan oxidative stress meningkat sehingga terjadi inflamasi dan mengganggu kerja Nitric Oxide (NO), dan akhinya memicu proses-proses yang meningkat tekanan darah sehingga sebelum terakumulasi di rambut, memungkinkan timbal di dalam darah mengganggu kerja tekanan darah (Vaziri et al., 2011).

Faktor lain dalam penelitian ini yang diduga sebagai faktor-faktor yang menyebabkan hipertensi antara lain kebiasaan merokok, kebiasaan minum kopi dan konsumsi makanan asin. Berdasarkan hasil analisis multivariat, diketahui bahwa faktor pengganggu hubungan kadar timbal di rambut dengan hipertensi yaitu konsumsi makanan asin dan kebiasaan minum kopi. Secara klinis responden yang mengkonsumsi makanan asin berisiko 2,4 kali untuk menderita hipertensi dan responden yang memiliki kebiasaan minum kopi berisiko 4,32 kali untuk mengalami hipertensi.

\section{KESIMPULAN}

Berdasarkan hasil penelitian dan pembahasan dapat disimpulkan sebagai berikut bah-

\section{DAFTAR RUJUKAN}

Beevers, D. G., Erskine, E., Robertson, M.,Beattie ,A.D., Camtimbalell, B. C., Goldberg, A., Moore, M. R and Hawthorne. Blood-Lead and hypertension.Journal the lancet,.1976:vol.308.

Daniel,L., Borges, G.,Silva,A.F.D and Curtlus. Determination of Lead in Coal Using Direct Solid Sampling and High-Resolution Continuum Source Graphite Furnace Atomic Absorption Spectrometry. Austria.Microchim Acta.2006: 154,101-107

Darmono. Lingkungan Hidup dan pencemaran (Hubungannnya dengan Toksikologi Senyawa wa terdapat kandungan logam berat timbal baik total maupun terlarut di dalam air sungai Bengkulu, terdapat hubungan yang bermakna antara kadar timbal di rambut dengan penyakit hipertensi dilihat dari nilai $\mathrm{p} 0,03<0,05$. Secara klinis berdasarkan nilai OR $(7,16)$ dengan mengontrol variabel kebiasaan merokok, konsumsi makanan asin dan kebiasaan minum kopi dapat dinyatakan bahwa kandungan timbal di dalam rambut dapat menyebabkan timbulnya risiko 7,16 kali untuk menderita hipertensi. Timbal didalam rambut merupakan faktor risiko yang paling berpengaruh terhadap penyakit hipertensi pada masyarakat pengumpul limbah batubara di sungai Bengkulu. Timbal merupakan logam berat yang berbahaya bagi manusia dan lingkungan, sehingga untuk mengurangi dampak negatif disarankan bagi peneliti selanjutnya yang ingin melakukan penelitian mengenai kadar timbal di rambut, sebaiknya melakukan penelitian dengan dampak kesehatan yang lain seperti gangguan terhadap sistem syaraf pusat atau mengurangi kecerdasan IQ.

Bagi Dinas kesehatan dan Badan lingkungan Hidup Provinsi Bengkulu, sebaiknya lebih menjadi perhatian mengenai masalah limbah batubara yang mencemari sungai kota Bengkulu, dan terlebih lagi air yang tercemar juga masih digunakan sebagai intake air PDAM dan bagi masyarakat pengumpul limbah batubara, sebaiknya dari hasil penelitian ini dapat menjadi peringatan pentingnya alat pelindung diri saat bekerja seperti menggunakan masker, baju dan celana panjang untuk mengurangi paparan timbal dalam tubuh.

Logam), Jakata: Universitas Indonesia Press; 2001.

Deyot,Y.K dan Sutomo,A.H. Masa Kerja, Kadar Timbal Darah Dan Kejadian Hipertensi Pada Petugas Parkir Di Jl. Malioboro Yogyakarta. Yogyakarta: Universitas Gadjah Mada;2003.

Farmand, F., Ehdaie, A., Roberts, C. H. K., Sindhu, R. K. Lead-InducedDysregulation of Superoxide Dismutases, Catalase, Glutathione Peroxidase andGuanylate.USA. Research,2005: 33-39. 
Kementerian Lingkungan Hidup. KLH Melakukan Pemantauan Kwalitas Air Sungai Di 33 Provinsi, Diakses Pada Tanggal13 September 2014 Dari Http://Www.Menlh.Go.Id/Klh-MelakukanPemantauan-Kwalitas-Air-Di-33-Provinsi/

Kubova,J.,Stersko,V.,Meved,J And Polakovicova,J. Analysis Of Human Hair- Reliable Tool For Monitoring Of Contamination Of Environmental Exposure. Bratislava.Acta Environmetalica universitas comenianae.1994; vol.2.

Marianti, A dan Prasetya, A.T. Rambut Sebagai Bioindikator Pencemaran Timbal Pada Penduduk Di Kecamatan Semarang Utara. Semarang:Jurnal biosantifika; 2013

Nordberg, G. Metal: chemical properties and toxicity. In: stellman JM (ed); encyclopedia of occupational health and safety. 4 ed. IL:Geneva; 1998.

Palar. H. Pencemaran dan Toksikologi Logam Berat. Jakarta: Rineka Cipta.2012: 78-86.

Pasorong, M.B., Kushadiwijaya.H.,Ng.N, Pribadi,V.Hubungan Antara Kadar Timbal (Timbal) Dan Hipertensi Pada Polisi Lalu Lintas Di Kota Manado. Yogyakarta: Berita Kedokteran Masyarakat; 2007: 81 - 88.

Pemerintah Propinsi Bengkulu. Penetapan Baku Mtu Air Dan Kelas Air Sungai Lintas Kabuapaten/Ota Dalam Propinsi Bengkulu. Peraturan Daerah Propinsi Bengkulu Nomor 56 Tahun 2005;2005.

Riyadina,W., Notosiswoyo, M., Sirait, A.M dan Tana,L.Hubungan antara Timbal (Timbal) dalam Darah dengan Hipertensi pada Operator Pompa
Bensin (STIMBALU).Buletin Penelitian Kesehatan. 2002; 30(2):81-87.

Sanna,E., Vargiu,L., Rosseti,I., Vallascas,E And Floris,G.Correlation between blood and hair lead levels in boys and girls of Sardinia (Italy). Italy: Jurnal of Anthropological sciences. 2007: 85. 173-181.

Santoso, B. Dampak aktivitas transportasi terhadap kandungan Pb (Timbal) Didalam rambut Polisis Lalu Lintas Kota Besar Semarang. Semarang: Uniersitas Diponegoro; 2012

Saptutyningsih,E. Dampak Negatif Partikel Debu Dan Timbal Dalam Gas Buang Kendaraan Bermotor Terhadap Kesehatan Masyarakat di Kabupaten Bantul.Yogyakarta: Jurnal Eko-Regional,.2009: Vol.4,No.2.

Vaziri, N. D \& Khan, M. Interplay of Reactive Oxygen Species and NitricOxide in The Pathogenesis of Experimental Lead-Induced Hypertension.Clinical and Experimental Pharmacology and Physiology. Dalam: Alghasham,A.A., Meki, A.R., Ismail, H.A. (2011). Association of Blood Lead Level with Elevated Blood Pressure in Hypertensive Patients. Qassim University, Saudi Arabia. InternationalJournal of Health Sciences,. 2007; 5; $1: 17-21$

WHO (2013). Q\&As On Hypertension. Diakses Pada $\begin{array}{llll}\text { Tanggal } & 30 \quad \text { April } 2015 \quad \text { Dari }\end{array}$ http://www.who.int/features/qa/82/en/.

Wiryono. Pengantar Ilmu Lingkungan. Bengkulu: Pertelon Media; 2013. 